\title{
ANALISIS KEMAMPUAN BERPIKIR REFLEKTIF DAN ANALITIK PESERTA DIDIK SMP DALAM MENYELESAIKAN SOAL MODEL PROGRAMME FOR INTERNATIONAL STUDENT ASSESSMENT (PISA)
}

\author{
Hasan Bashri Hadimu ${ }^{1 *}$, Theresia Laurens², La Moma ${ }^{3}$ \\ 1,2,3Program Studi Magister Pendidikan Matematika, Pascasajana, Universitas Pattimura \\ Jalan Ir. Putuhena, Kampus Unpatti, Poka, Ambon, Indonesia \\ e-mail: ${ }^{1}$ hasanbashrihadimu@ gmail.com; \\ Submitted: August 20, $2020 \quad$ Revised: September 23, $2020 \quad$ Accepted: September 28, 2020 \\ corresponding author*
}

\begin{abstract}
During this time, reflective thinking and analytical skills have not been one of the objectives of mathematics and learners have not demonstrated reflective activity and analytic learning. The ability of the students ' reflective thinking and analytics is an important aspect to be examined and developed so that the learner's math learning is more optimal. The study aims to describe the ability of the students ' reflective thinking and analytic of junior high school in solving the Programme for International Student Assessment (PISA) model. This research is a qualitative descriptive study describing the reflective thinking skills and analytical students of junior high school in solving the Programme for International Student Assessment (PISA) model. The subject in this study is a class IX student consisting of three learners with the details of each of the 1 learners with reflective thinking skills, 1 student with analytic thinking skills and 1 student with reflective and analytical thinking skills. The data collection techniques used are tests of reflective thinking and analytical skills as well as interviews. Test Data and interviews are analyzed based on indicators that meet the ability of reflective thinking and analytical thinking skills. Data analysis techniques refer to the Miles and Hiberman concepts which include data reduction, data presentation, and conclusion withdrawal. Data validity techniques use observer persistence, triangulation time and peer checking. The results of the study provide conclusions: 1) Subject 1 meets the indicator of the reflective thinking ability, subject 1 able to the reacting phase, comparing, less in the contemplating phase: 2) Subject 2 meets the analytical thinking ability indicator, subject 2 is capable at would phase, organizing and attributing: 3) Subject 3 meets the indicator of reflective thinking capabilities capable of the reacting, comparing, contemplating and subject 3 , organizing and attributing.
\end{abstract}

Keywords: analytics, reflective, pisa

\section{Pendahuluan}

Selama ini kemampuan berpikir reflektif dan analitik belum menjadi salah satu tujuan pembelajaran matematika. Hal ini sejalan dengan pernyataan dari Sabandar (2010: 3) bahwa berpikir reflektif masih jarang diperkenalkan oleh guru atau dikembangkan untuk peserta didik sekolah menengah. Nindiasari (2014: 82) menemukan bahwa lebih dari $60 \%$ peserta didik sekolah menengah belum mampu mencapai berpikir reflektif matematis, seperti kemampuan mengintepretasi, mengaitkan, dan mengevaluasi.

Dewey

(Rodgers, 2002:

Mengemukakan tentang pentingnya berpikir reflektif sebagai berikut. "Reflective thinking is the arrangement of understandable thoughts. These thoughts become what one believes or does not believe. They are often influenced by experiences".
Berpikir reflektif adalah pengaturan tentang berpikir untuk menyelesaikan suatu masalah. Berpikir reflektif menjadikan seseorang yakin atau tidak yakin terhadap penyelesaian suatu masalah.

Rudd dan Shermis (Gurol, 2011: 388) menyatakan tentang pentingnya bepikir reflektif sebagai berikut. "An important role of reflective thinking is to act as a means of prompting the thinker during problem solving situations because it provides an opportunity to step back and think of the best strategies ot achieve goa. Reflective thinking helps to integrate these thinking skills by helping with judgments, Berpikir reflektif memiliki peranan penting sebagai sarana bepikir untuk menyelesaikan masalah matematika. Berpikir reflektif memberikan kesempatan pada peserta didik untuk belajar memikirkan strategi terbaik dalam mencapai tujuan pembelajaran. Selain itu

Copyright (c) Authors. This is an open access article distributed under the Attribution-NonCommercial-

ShareAlike 4.0 International (CC BY-NC-SA 4.0), which permits unrestricted use, distribution, and reproduction in any medium, provided the original work is properly cited. 
berpikir reflektif dapat membantu peserta didik mengintegrasikan kemampuan berpikirnya dengan melakukan penilaian. Dengan demikian, berpikir reflektif merupakan hal yang penting agar peserta didik mampu memecahkan masalah secara optimal.

Dengan demikian, kemampuan berpikir reflektif ialah kemampuan peserta didik dalam mengklasifikasi makna pengalaman belajar dulu dan sekarang, proses mental yang kompleks dalam memahami, mengkritik, menilai, mencari solusi alternatif dan mengevaluasi isu atau masalah yang dipelajari dalam kaitannya dengan masalah yang dihadapi dalam dunia nyata.

Sulastri (2018: 78) salah satu aspek kognitif dalam taksonomi Bloom yang menempati urutan keempat setelah pengetahuan, pemahaman, dan aplikasi adalah aspek analitik. Kemampuan berpikir analitik merupakan suatu kemampuan dasar yang harus dimiliki oleh peserta didik.

Menurut Amer (2005: 1), “analythical thinking is a powerful thinking tool-for understanding the parts of situation is the ability to scrutinize and break down facts and thought into their strengths and weaknesses", Berpikir analitik sangat berguna untuk memahami bagian-bagian dari situasi, kemampuan untuk meneliti dan merinci fakta dan berpikir pada kekuatan dan kelemahannya.

Parta (2016: 1) Berpikir analitik merupakan salah satu model berpikir yang perlu dikembangkan dalam pembelajaran matematika. Model berpikir ini sangat dibutuhkan karena obyek kajian dalam pembelajaran matematika merupakan obyek abstrak. Sedangkan menurut Sternberg (2012: 424) mengatakan it is important to teach students not just to learn facts but also to think analytically, creatively, practically, and wisely. Jadi menurut Sternberg bahwa penting untuk mengajar peserta didik tidak hanya untuk belajar fakta tetapi juga untuk berpikir secara analitis, kreatif, praktis, dan bijaksana. Oleh karena itu, berpikir analitik sangat berperan bagi peserta didik, khususnya pada proses pemecaham masalah matematika.

Dari uraian di atas, maka dapat simpulkan kemampuan berpikir analitik ialah kemampuan dasar yang harus dimiliki peserta didik dalam menyelesaikan soal non rutin yang membutuhkan unsur pengetahuan, pemahaman aplikasi, menemukan hubungan, membuktikan, mengomentari dan menggeneralisasi

Sternberg, dkk (2012:22) mengatakan teaching students to use all of their analytic, creative, and practical abilities has resulted in improved school achievement for every student, whatever their ability pattern, Mengajar peserta didik untuk menggunakan semua kemampuan analitik, kreatif, dan praktis mereka telah menghasilkan peningkatan prestasi sekolah untuk setiap peserta didik, apa pun pola kemampuan mereka.

Muin (2011: 234) menyatakan bahwa keterampilan berpikir reflektif peserta didik perlu dimiliki, tidak hanya dalam proses pembelajaran, tetapi juga berkaitan dengan memecahkan masalah kehidupan sehari-hari. Karena dengan berpikir reflektif, seseorang dapat memahami, mengkritik, menilai, mencari solusi alternatif, dan mengevaluasi isu atau masalah yang dipelajari. Jika dikaitkan dengan PISA berdasarkan OECD (2014), soal matematika PISA erat kaitannya dengan kemampuan menginterpretasi hal-hal matematis pada berbagai konteks yang berbeda dan membantu seseorang untuk memahami peran matematika pada situasi kehidupan nyata serta membuat penilaian dan keputusan. Dengan demikian berpikir reflektif sangat dibutuhkan dalam memecahkan masalah yang terkait dengan masalah matematika standar PISA

Kurniati dan Jamil (2016: 143) Soal-soal PISA bukan hanya menuntut kemampuan dalam penerapan konsep saja, tetapi lebih kepada bagaimana konsep itu dapat diterapkan dalam berbagai macam situasi. Selanjutnya, Setiawan (2014) mengemukakan soal PISA selain menuntut kemampuan analisis dalam pengerjaannya. Dengan demikian, kemampuan berpikir reflektif dan analitik sangat berperan penting dalam menyelesaikan soal PISA.

\section{Metode Penelitian}

Metode penelitian yang digunakan dalam penelitian ini adalah penelitian deskriptif kualitatif. Penelitian ini bertujuan untuk mendeskripsikan kemampuan berpikir reflektif dan analitik peserta didik SMP dalam menyelesaikan soal model Programme for International Student Assessment (PISA). Prosedur penelitian ini terdiri dari 3 tahapan utama yaitu persapan, implementasi dan analisis data. Pada tahap persiapan, peneliti mempersiapkan instrumen tes (soal-soal PISA) untuk mengukur kemampuan berpikir reflektif dan analitik peserta didik. Terdapat 2 soal PISA yang harus diselesaikan peserta didik. Selanjutnya peneliti menganalisis jawaban peserta didik untuk mengetahui dan mendeskripsikan kemampuan berpikir reflektif dan analitik peserta didik. Penelitian ini dilakukan di MTsN Ambon dan SMP 
Advent Maluku. Subjek penelitian ini adalah 3 peserta didik kelas IX yang memenuhi indikator kemampuan berpikir reflektif, analitik dan reflektif analitik. Pemilihan subjek berdasarkan pertimbangan peserta didik tersebut mampu menyelesaikan soal PISA, mampu berkomunikasi dengan baik terkait dengan penyelesaian soal PISA dan pertimbangan guru bidang studi.

Tabel 1. Indikator Kemampuan Berpikir Reflektif dan Analitik dalam Menyelesaikan Soal Model PISA

\begin{tabular}{|c|c|}
\hline $\begin{array}{c}\text { Fase Berpikir } \\
\text { reflektif }\end{array}$ & Indikator Berpikir Reflektif \\
\hline Reacting & $\begin{array}{l}\text { Peserta didik mampu menyebutkan } \\
\text { dan menghubungkan hal-hal yang } \\
\text { diketahui dan ditanyakan pada soal, } \\
\text { mampu menjelaskan bahwa yang } \\
\text { diketahui sudah cukup atau belum } \\
\text { untuk menjawab yang ditanyakan } \\
\text { dalam menyelesikan soal PISA }\end{array}$ \\
\hline Comparing & $\begin{array}{l}\text { Peserta didik mampu menjelaskan } \\
\text { permasalahan yang pernah } \\
\text { diperoleh dan menghubungkan } \\
\text { masalah yang ditanyakan dengan } \\
\text { masalah yang pernah dihadapi } \\
\text { dalam menyelesaikan soal PISA }\end{array}$ \\
\hline Contemplating & $\begin{array}{l}\text { Peserta didik mampu menjelaskan } \\
\text { maksud permasalahan, mendeteksi } \\
\text { kesalahan pada penentu jawaban, } \\
\text { dan membuat kesimpulan dengan } \\
\text { benar dalam menyelesaikan soal } \\
\text { PISA }\end{array}$ \\
\hline $\begin{array}{c}\text { Fase Berpikir } \\
\text { Analitik } \\
\end{array}$ & Indikator Berpikir Analitik \\
\hline Differentiating & $\begin{array}{l}\text { Memilah-milah bagian-bagian yang } \\
\text { relevan dan tidak relevan dalam } \\
\text { menyelesakan soal PISA }\end{array}$ \\
\hline Organizing & $\begin{array}{l}\text { Membuat struktur dalam } \\
\text { penyelesaian masalah yang } \\
\text { sistematis dalam menyelesakan soal } \\
\text { PISA }\end{array}$ \\
\hline Attributing & $\begin{array}{l}\text { Mengungkapkan informasi dalam } \\
\text { bentuk kesimpulan dalam } \\
\text { menyelesakan soal PISA }\end{array}$ \\
\hline $\begin{array}{c}\text { Fase Berpikir } \\
\text { Reflektif dan } \\
\text { Analitik } \\
\end{array}$ & $\begin{array}{c}\text { Indikator Berpikir Reflektif dan } \\
\text { Analitik }\end{array}$ \\
\hline Reacting & $\begin{array}{l}\text { Peserta didik mampu menyebutkan } \\
\text { dan menghubungkan hal-hal yang } \\
\text { diketahui dan ditanyakan pada soal, } \\
\text { mampu menjelaskan bahwa yang } \\
\text { diketahui sudah cukup atau belum } \\
\text { untuk menjawab yang ditanyakan } \\
\text { dalam menyelesikan soal PISA }\end{array}$ \\
\hline Comparing & $\begin{array}{l}\text { Peserta didik mampu menjelaskan } \\
\text { permasalahan yang pernah } \\
\text { diperoleh dan menghubungkan } \\
\text { masalah yang ditanyakan dengan } \\
\text { masalah yang pernah dihadapi } \\
\text { dalam menyelesaikan soal PISA } \\
\end{array}$ \\
\hline
\end{tabular}

\begin{tabular}{cl}
\hline \multirow{3}{*}{ Contemplating } & $\begin{array}{l}\text { Peserta didik mampu menjelaskan } \\
\text { maksud permasalahan, mendeteksi } \\
\text { kesalahan pada penentu jawaban, } \\
\text { dan membuat kesimpulan dengan } \\
\text { benar dalam menyelesaikan soal } \\
\text { PISA }\end{array}$ \\
\hline \multirow{3}{*}{ Differentiating } & $\begin{array}{l}\text { Memilah-milah bagian-bagian yang } \\
\text { relevan dan tidak relevan dalam } \\
\text { menyelesakan soal PISA }\end{array}$ \\
\hline \multirow{2}{*}{ Organizing } & $\begin{array}{l}\text { Membuat struktur dalam } \\
\text { penyelesaian masalah yang } \\
\text { sistematis dalam menyelesakan soal } \\
\text { PISA }\end{array}$ \\
\hline & $\begin{array}{l}\text { Mengungkapkan informasi dalam } \\
\text { bentuk kesimpulan dalam } \\
\text { menyelesakan soal PISA }\end{array}$ \\
\hline
\end{tabular}

\section{Hasil dan Pembahasan}

\subsection{Hasil}

Berikut ini adalah deskripsi kemampuan berpikir reflektif subjek dalam menyelesaikan soal PISA.

\section{Subjek 1 dalam menyelesaikan soal PISA \\ a. Fase Reacting}

Subjek 1 melakukan fase reacting pada masalah I dan II.

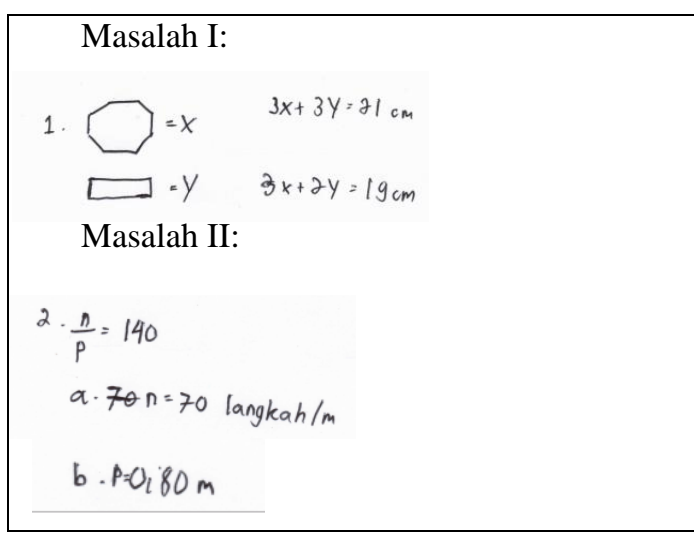

Gambar 1. Hasil Subjek 1 Fase Reacting

Berdasarkan Gambar 1, terlihat bahwa pada masalah I dan II, subjek 1 dapat menuliskan informasi yang diketahui sesuai dengan masalah yang diberikan, namun tidak menuliskan apa yang ditanyakan pada soal. Ketika wawancara dilakukan, subjek mampu mengemukakan apa yang ditanyakan pada soal subjek 1 mampu menguraikan masalah dengan pemahamannya sendiri, serta mampu menghubungkan apa yang diketahui dan ditanyakan pada soal.

Petikan wawancara Subjek 1 berkaitan dengan fase reacting sebagai berikut: 
P 06 : Coba kemukakan dengan bahasamu sendiri tentang masalah 1 !

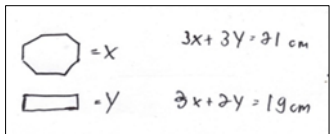

Gambar a. Hasil Pekerjaan Subjek 1 memisalkan segi enam dengan $x$ dan persegi panjang dengan $y$

Soalnya menggunakan rumus aljabar (menunjuk hasil pekerjaan)

S1.06 : Misalnya bangun datar segi empat ialah $x$ dan persegi panjang ialah $y$, maka bisa dikatakan $3 x+3 y=21 \mathrm{~cm}$ dan $3 x+$ $2 y=19 \mathrm{~cm}$

P 07 : Apa yang ditanyakan dari soal ?

S1.07: $x+2 y ?$ (untuk tower terpendek)

P 08 : Apa hubungan antara yang di tanyakan dan diketahui ?

S1.08 : Hubungannya ialah persamaan $3 x+$ $3 y=21$ dan $3 x+2 y=19$ itu sangat penting untuk kita gunakan untuk menentukn nilai $x+2 y$ (untuk tower terpendek)

P 09 : Apakah yang diketahui dan yang ditanyakan sudah cukup untuk menjawab soal ini ?

S1.09 : Cukup

P 15 : Dari masalah II, Informasi apa saja yang diketahui ?

$2 \cdot \frac{n}{p}=140$
$a \cdot 70 n=70$ langkah/m
$\frac{n}{p}=140 \rightarrow \frac{n}{0.80}=140$

Gambar b. Hasil Pekerjaan Subjek 1 dalam menuliskan informasi dalam penyelesaian soal

S1.15 : Misal (sambil menunjuk) jarak antar kedua kaki ialah $p$, dan $n$ ialah kecepatan langkah/meter dan kita harus tentukan nilai $P$ atau panjang langkah dalam meter dan $n$ atau Kecepatan Berjalan dalam meter per menit

P 16 : Apa hubungan dari yang diketahui dan yang ditanyakan pada soal?

S1.16 : Jika diketahui $n$, kita disuruh mencari $p$, dan jika diketahui $p$, kita disuruh mencari $n$.

P 17 : Setelah memahami apa yang diketahui dan ditanyakan pada soal, apakah itu cukup untuk menyelesaikan soal?

S1.17 : Cukup

\section{b. Fase Comparing}

Subjek 1 melakukan fase comparing

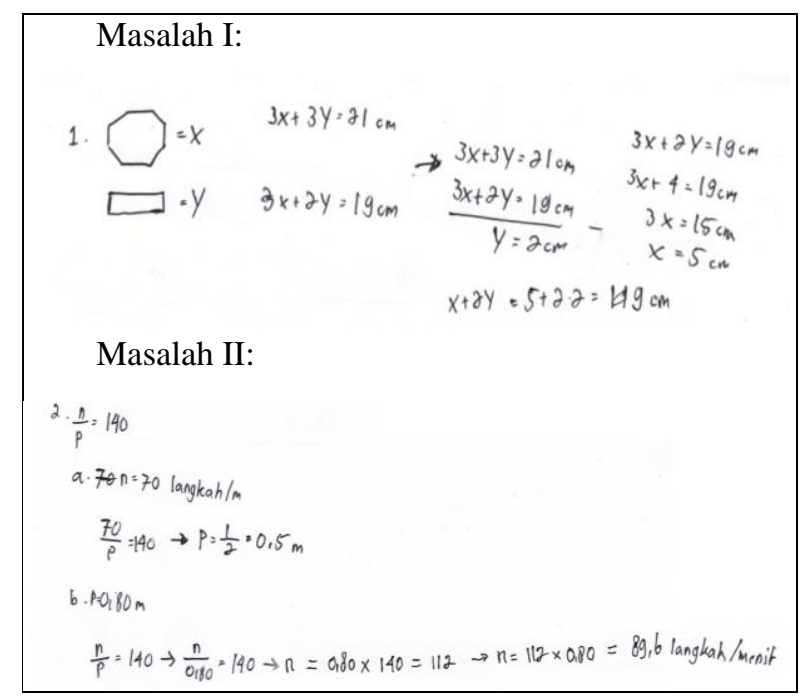

Gambar 2. Hasil Subjek 1 Fase Comparing

Subjek 1 mampu menjelaskan jawaban dengan permasalahan yang pernah didapatkan dan mampumenghubungkan masalah yang ditanyakan dengan masalah yang pernah dihadapi. Berdasarkan uraian di atas, maka dapat disimpulkan bahwa pada fase comparing, subjek 1 mampu dalam menjelaskan masalah yang pernah dihadapi dan menghubungkan masalah yang pernah dihadapi dengan masalah yang di selesaikan sekarang.

Petikan wawancara Subjek 1 berkaitan dengan fase comparing sebagai berikut:

P 10 : Pada soal no 1, Apakah pernah memecahkan soal seperti ini sebelumnya?

S1.10 : Pernah

P 11 : Coba jelaskan masalah yang pernah di hadapi?

S1.11 : Saya pernah menyelesaikan masalah seperti ini sebelumnya. Misal

$2 x-y=3$

$3 x-4 y=7$

Dengan menggunakan metode eliminasi kita peroleh $y=-1$

Selanjutnya kita gunakan metode subtitusi untuk persamaan pertama agar kita dapat menentukan nilai y

$2 x-y=3$

$2 x-(-1)=3$

$2 x+1=3$

$2 x=3-1$

$2 x=2$

$x=1$

Jadi, nilai $x=1$ dan $y=-1$

P 12 : Coba anda jelaskan hubungan antara soal yang pernah diselesaikan dengan soal yang dijawab sekarang?

S1.12 : Hubungannya terletak pada cara menyelesaikannya yaitu dengan cara subtitusi dan eliminasi 
P 18 : Baik cukup!

Selanjutnya, Pada soal no 2 Apakah pernah menyelesaikan soal seperti ini sebelumnya?

S1.18 : Pernah, soal ini berkaitan dengan perbandingan senilai. Konsep tentang perbandingan senilai $\frac{a}{b}=\frac{c}{d}$ dimana $a \times$ $b=c \times d$.

P 19 : Jadi, apa hubungannya dengan soal yang kamu jawab sekarang ?

S1.19 : Nah, konsep perbandingan senilai sangat penting untuk memecahkan soal no 2.

Misalnya tadi, $\frac{n}{p}=140=\frac{70}{p}=140$ maka $p=\frac{70}{140}=\frac{1}{2}=0,5$

P 20 : Jadi hubungannya dengan konsep perbandingan senilai ialah untuk menentukan nilai $\mathrm{D}$, maka $D=\frac{a \times b}{c}$ sama halnya dengan $p=\frac{70 \times 1}{140}$ Baik, Cukup!

\section{c. Fase Contemplating}

Subjek 1 melakukan fase contemplating pada masalah I dan II.

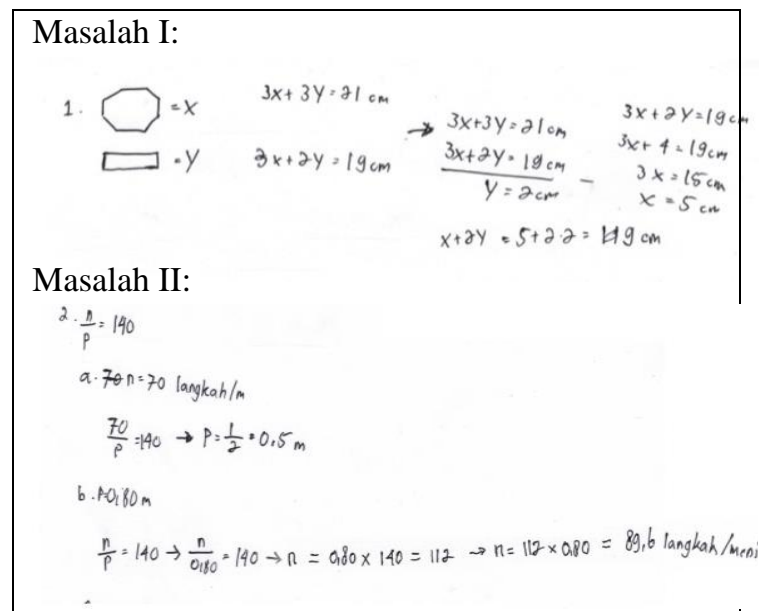

Gambar 3. Hasil Subjek 1 Fase Contemplating

Berdasarkan Gambar 3, terlihat bahwa subjek I mampu menjelaskan permasalahan pada soal, memperbaiki dan menjelaskan kesalahan yang terjadinamun cenderung tidak menuliskan kesimpulan. Sehingga dapat disimpulkan bahwa pada fasecontemplating subjek 1 mampu dalam menjelaskan maksud permasalahan dan kesimpulan. Hal ini diperkuat dengan pernyataan (Ananda, 2019: 143), peserta didik mengalami kesulitan pada fase berpikir reflektif yang ketiga yaitu contemplating (berpikir refletif untuk inkuiri kritis), dimana peserta didik tidak mampu membuktikan kebenaran jawaban.

Petikan wawancara Subjek 1 berkaitan dengan fase contemplating sebagai berikut:
P 13 : Dari soal no 1, kira-kira apa maksud dari soal?

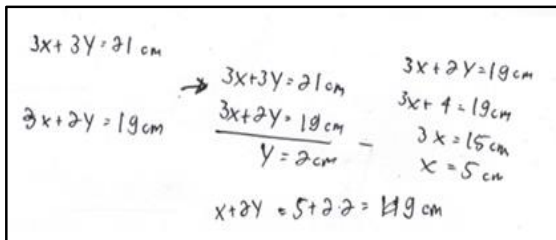

Gambar c. Hasil Pekerjaan Subjek 1 menggunakan metode eliminasi dan substitusi

S1.13 : Dari persamaan ini (menunjuk hasil pekerjaan), kita menggunakan subtitusi dan eliminasi untuk mencari panjang bangun ini (menunjuk soal)

Pertama, kita misalkan bangun datar segi enam adalah $x$ dan persegi panjang adalah $y$. Selanjutnya berdasarkan informasi dari soal kita tulis persamaan yaitu $3 x+3 y=21 \mathrm{~cm}$ dan $3 x+2 y=$ $19 \mathrm{~cm}$.

Setelah itu kita lakukan metode eliminasi pada $\mathrm{x}$, dan kita peroleh nilai $y=2$. Selanjutnya kita tulikan persamaan $\quad 3 x+2 y=19 \mathrm{~cm}$ dan subtitusikan nilai $y=2$, sehingga kita peroleh nilai $x=5$. Pada langkah terakhir, $x+2 y=5+2.2=9$

P 14 : Apakah dalam mengerjakan soal, terjadi kesalahan dan anda mengoreksinya ?

S1.14 : Tidak

\section{Subjek 2 dalam menyelesaikan soal PISA \\ a. Fase Differentiating}

Subjek 2 melakukan fase differentiating pada masalah I dan II.

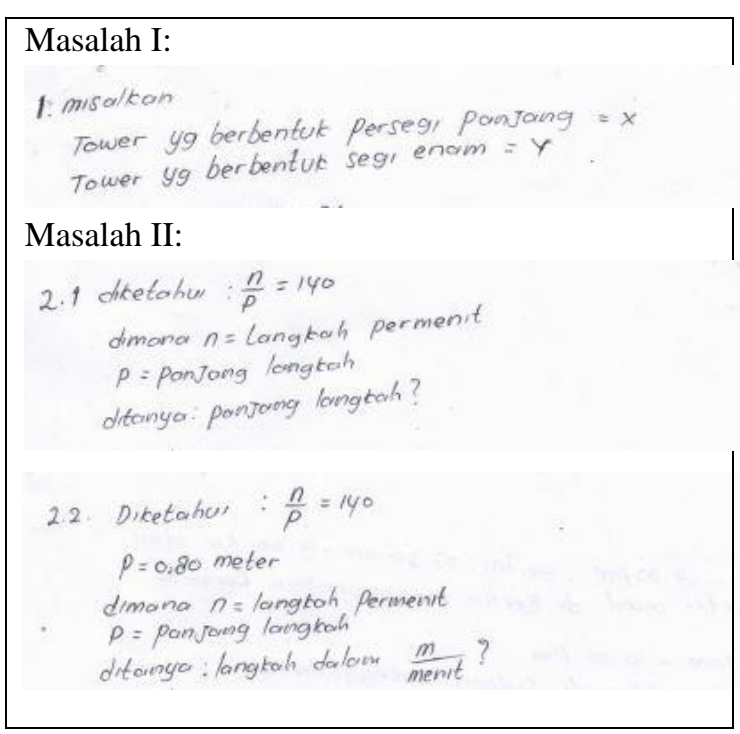

Gambar 4. Hasil Subjek 2 Fase Differentiating

Berdasarkan Gambar 4, terlihat bahwa pada masalah I dan II, subjek 2 mampu menuliskan langkah-langkah penyelesaian masalah secara runtut. Pada jawaban di atas, terlihat bahwa subjek 
2 memenuhi aspek memilih (differentiating) yaitu mampu mengelompokkan data-data yang berkaitan dengan permasalahan yang diberikan. Pada masalah I Subjek 2 menuliskan data yang diketahui dari permasalahan namun tidak menuliskan apa yang ditanyakan. Ketika wawancara dilakukan, subjek 2 mampu mengemukakan apa yang ditanyakan pada soal. Kemudian pada masalah II, subjek 2 menuliskan data yang diketahui dan yang ditanyakan pada soal.

Petikan wawancara Subjek 2 berkaitan dengan fase differentiating sebagai berikut:

P 04: $\begin{aligned} & \text { Kira-kira, informasi apa saja yang adik } \\ & \text { peroleh dari soal no } 1 \text { ? }\end{aligned}$
$\mathrm{S} 2.04: \begin{aligned} & \text { 1: misalkan } \\ & \text { Tower yg berbentuk perseg, panjang }=x \\ & \text { Tower yg berbentuk seg, enam }=y \\ & \text { maka: } \begin{array}{l}3 x+3 y=21 \\ 2 x+3 y=19\end{array} \\ & x=2\end{aligned}$

Gambar f. Hasil Pekerjaan Subjek 2 dalam menuliskan informasi pada soal ada 2 tower dengan tinggi yang berbeda kak. Terus itu tower terbentuk dari persegi panjang dan segienam yang tersusun. Jadi segienam kumisalkan $x$ dan persegi panjang kumisalkan $y$ Jadi kutulis diketahui $3 x+3 y=21$ dan $3 x+2 y=19$.

P 05 : Kalau yang ditanyakan?

S2.05 : Itu tingginya tiang yang paling pendek kak.

P 06 : Bangun apa yang bentuk tower paling pendek?

S2.06 : Samaji itu kak tower 1 dan 2, persegi panjang dan segienam yang bentuknya tower paling pendek.

P 07 : Jadi?

S2.07 : Astaga.. ada kulupa kak disini (sambil menunjuk lembar jawaban) harusnya kutulis $x+2 y$. Kutulis di cakaranku itu kak tapi lupa tulis di sini.

P 08 : Oke lanjut. Itu simbol $x$ dan $y$ dapat diganti symbol lain?

S2.08 : Bisa kak.

P 09 : Nah, apakah adik masih butuh informasi tambahan untuk menyelesaikan soal nomor 1 ?

S2.09 : Cukup kak kalau menurutku.

P 14 : Oke dek. Sekarang perhatikan lagi soal nomor 2. Bagaiamana menurut adik soal nomor 2?

S2.14 : Awalnya bingung kak jadi nda mengertika kak tapi gampang ternyata (sambil tersenyum)

P 15 : Coba jelaskan informasi apa saja yang diperoleh dari soal no 2 ?
S2.15

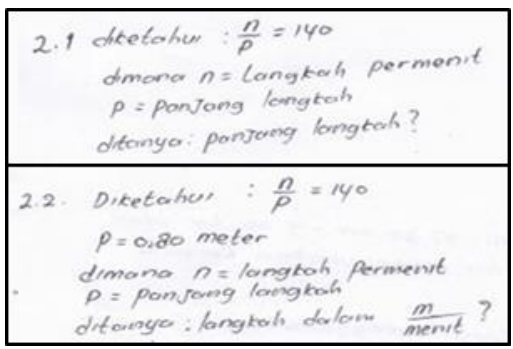

Gambar g. Hasil Pekerjaan Subjek 2 dalam menuliskan informasi yang dketahui dan ditanya dalam penyelesaian soal

Diketahui $n / p=140$ dengan $\mathrm{n}=$ langkah permenit, dan $\mathrm{p}=$ panjang langkas

P 16 : Baik. Apa ide setelah dibaca ini soal?

S2.16 : hmm. Awalnya kak tidak mengerti sekali ini soal, tapi setelah kubaca berulang-ulang bisa paham sedikit kak.

P 17 : Apa yang harus dimisalkan dengan menggunakan simbol?

S2.17 : Ini kak aku misalkan itu $n=$ langkah permenit, $p=$ panjang langkah. Jadi beripikir

P 18 : Jadi intinya setelah dibaca berulangulang bisa di paham informasi dari soal?

S2.18 : Iya kak.

P 19 : Kalau yang ditanyakan?

S2.19 : Kalau yang ditanyakan ini kak pertama $\mathrm{p}$ atau panjang langkah dan langkah dalam meter/menit

P 20 : Menurut kamu informasi yang dipahami apakah sudah cukup untuk menyelesaikan soal?

S2.20 : Cukup kak

\section{b. Fase Organizing}

Subjek 2 melakukan fase organizing pada masalah I dan II.

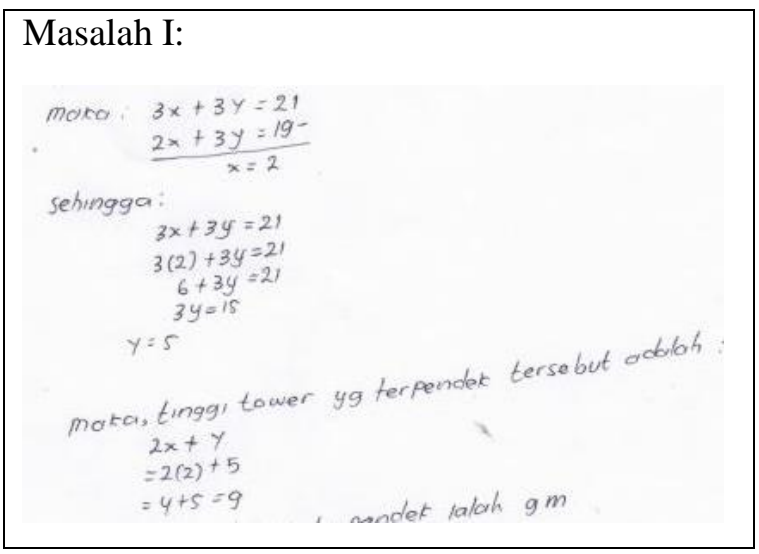




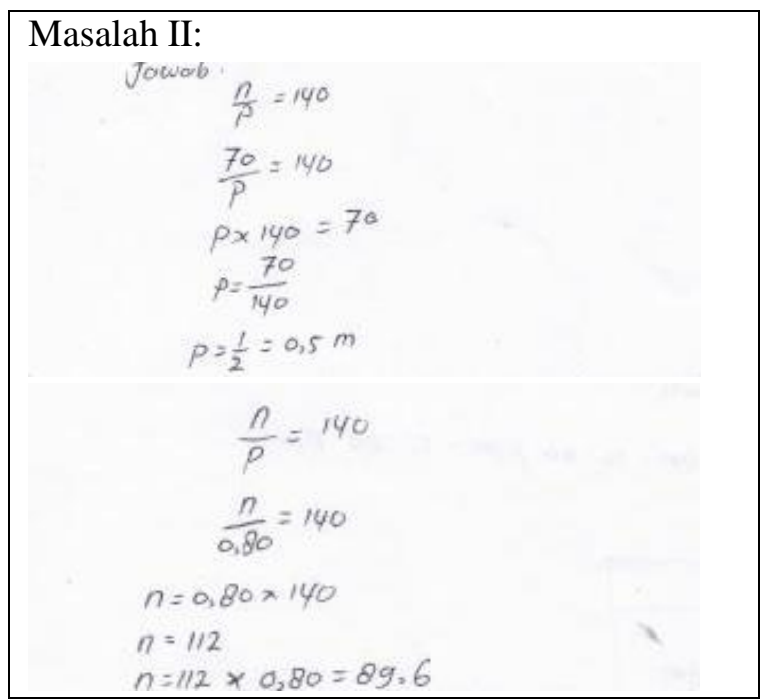

Gambar 5. Hasil Subjek 2 Fase Organizing

Berdasarkan Gambar 5, terlihat bahwa pada masalah I dan II, subjek 2 mampu menuliskan langkah-langkah penyelesaian secara runtut. Pada jawaban di atas, terlihat bahwa subjek S2 memenuhi aspek organizing yaitu mampu membuat struktur dalam penyelesaian masalah yang sistematis.

Subjek 2 menyusun struktur cara menyelesaikan masalah dengan cara menuliskan persamaan berdasarkan informasi yang diketahui pada soal. Pada masalah I subjek 2 menggunakan metode eliminasi dan subtitusi. Subjek 2 terlebih dahulu mengeliminasi nilai $3 y$ untuk dapat menentukan nilai $x$. Pada tahap selanjutnya subjek 2 menuliskan persamaan $3 x+3 y=21$. Kemudian mensubtitusikan nilai $x=2$ ke dalam persamaan. Sehingga diperoleh nilai $y=5$. pada tahap selanjutnya subjek $\mathrm{S} 2$ menuliskan persamaan $2 x+y=2(2)+5=9$. pada masalah II subjek S2 menggunakan konsep perbandingan senilai. Berdasarkan informasi dari soal, $\frac{n}{p}=$ 140 selanjutnya subjek S2 mensubtitusikan nilai $n=70$ sehingga, $\frac{70}{p}=140$. Maka $p=\frac{70}{140}=\frac{1}{2}=$ 0,5 sehingga diperoleh panjang langkah ialah 0,5 $\mathrm{m}$. selanjutnya untuk menentukan panjang langkah $\mathrm{m} /$ menit, subjek 2 mensubtitusikan nilai $p=$ 0,80 . Sehingga diperoleh $\frac{n}{0,80}=140$. Maka, $n=$ $0,80 \times 140=112 \cdot n=112 \times 0,80=89,6$.

Dengan demikian, subjek 2 mampu dalam membuat struktur dalam penyelesaian masalah yang sistematis, menjelaskan strategi dan langkahlangkah dalam menyelesaikan soal.

Petikan wawancara Subjek 2 berkaitan dengan fase organizing sebagai berikut:

P 10 : Setelah kamu mengetahui apa yang diketahui dan apa yang ditanyakan lalu kamu apakan lagi?
S2.10 : Mencari jawabannya pak dengan cara subtitusi dan eliminasi.

P 11 : Bagaimana menjawabnya?

S2.11

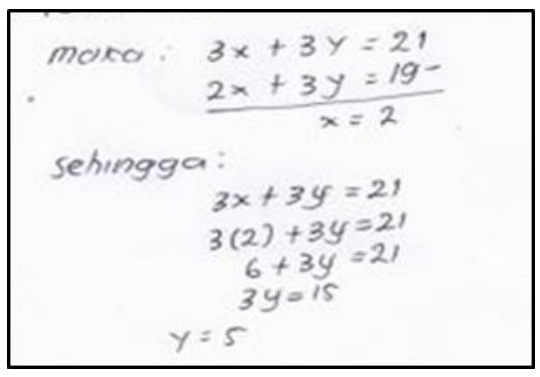

Gambar h. Hasil Pekerjaan Subjek 2 metode eliminasi dan substitusi

Kan yang diketahui dari tower a $3 x+$ $3 y=21$ dan tower b $2 x+3 y=19$ lalu di eliminasi untuk menentukan nilai $\mathrm{x}$ setelah itu di subtitusikan ke $3 x+$ $3 y=21$ untuk menentukan nilai $y$

Kita permisalkan dulu persamaan pertama dan kedua sesuai dengan informasi pada soal, itu sangat penting untuk dapat menyelesaikan soal

P 12 : Bagaimanakah strategi dan langkahlangkah dalam menyelesaikan soal ?

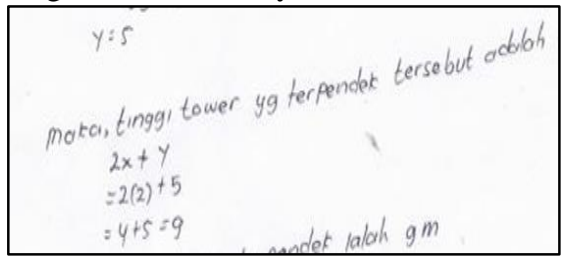

Gambar i. Hasil Pekerjaan Subjek 2 dalam menerapkan strategi atau langkah penyelesaian soal

S2.12 : Pertama pahami maksud dari soal, menuliskan persamaan dan menggunakan metode eliminasi dan subtitusi

P 21 : Setelah kamu memahami informasi pada soal 2.1 apa yang kamu lakukan?

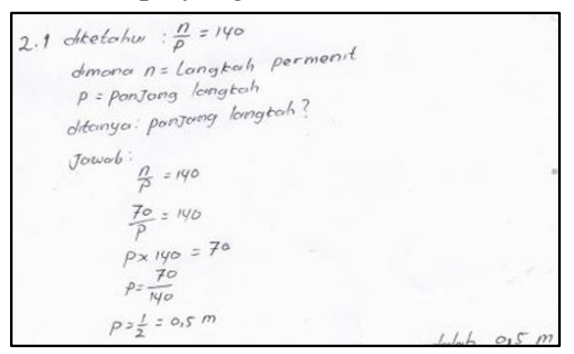

Gambar j. Hasil Pekerjaan Subjek 2 dalam menuliskan kesimpulan

S2.21 : Menulis rumusnya lalu memasukkan ke rumus yang diketahui dimana $\mathrm{n} / \mathrm{p}=140$ jadi 70 per $\mathrm{p}=140$ lalu $\mathrm{P}=70 / 140$ atau $1 / 2$ atau 0,5 meter

P 22 : Bagaimanakah strategi dan langkahlangkah dalam penyelesaian?

S2.22 : Karena soal ini berkaitan dengan perbandingan senilai, maka strateginya cukup dengan memahami soal dan harus bias operasi perkalian dan pembagian 
P 24 : Pada soal no 2.2, bagaimanakah sehingga kamu menentukan jawaban?

S2.24

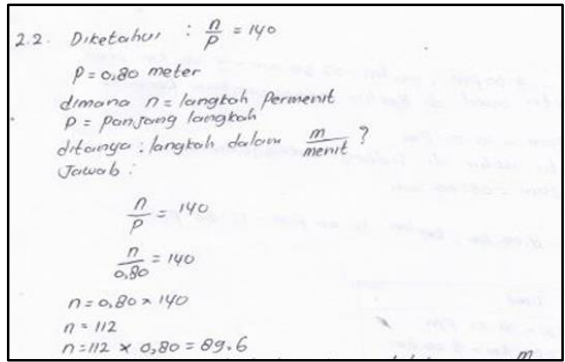

Gambar k. Hasil Pekerjaan Subjek 2 berkaitan dengan strategi dan langkahlangkah dalam penyelesaian soal

Dengan perbandingan senilai, sama kayak nomor 2.1 tapi bedanya yang dicari n nya jadi $\mathrm{n}=\mathrm{P} \times 140$ kan $\mathrm{P}$ nya 0,80 jadi $0,80 \times 140=112$ meter $/$ menit

P 25 : lalu dikali kan panjang langkah Budi hasilnya 89,6 meter

S2.25 : Bagaimanakah strategi dan langkahlangkah dalam penyelesaian?

Pertama pahami maksud dari soal, setelah itu kita gunakan perbandingan senilai dan masukan nilai panjang langkah, maka diperoleh $n=0.80 \times 140=112$ Setelah itu, $n=112 \times 0.80=89,6$ meter permenit

\section{c. Fase Attributing}

Subjek 2 melakukan fase attributing pada masalah I dan II.

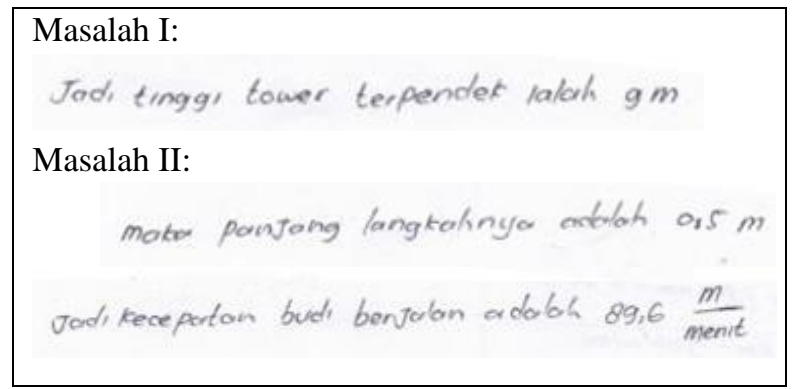

Gambar 6. Hasil Subjek 2 Fase Attributing

Berdasarkan Gambar 6, terlihat bahwa pada masalah I dan II, subjek 2 mampu menuliskan informasi dalam bentuk kesimpulan. Pada jawaban di atas, terlihat bahwa subjek S2 memenuhi aspek attributing yaitu mampu membuat kesmpulan berdasakan informasi yang diperoleh.

Berdasarkan uraian di atas, maka dapat disimpulkan bahwa pada fase Attributing, subjek 2 mampu dalam menuliskan kesimpulan di akhir jawaban.

Petikan wawancara Subjek 2 berkaitan dengan fase attributing sebagai berikut:

P 13 : Pada soal no 1, apa kesimpulan yang bisa diperoleh?
$=4+5=9$
Jadi tingg, tower terpendet lalah $9 \mathrm{~m}$

Gambar Hasil Pekerjaan Subjek 2 dalam menuliskan kesimpulan

S2.13 : Jadi, tinggi tower terpendek adalah 9m.

P 22 : Pada soal no 2.1 apa kesimpulan yang bisa diperoleh?

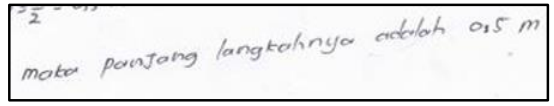

Gambar m. Hasil Pekerjaan Subjek 2 dalam menuliskan kesimpulan

S2.23 : Jadi, panjang langkahnya ialah 0,5 m

P 26 : Pada soal no 2.2 apa kesimpulan yang bisa diperoleh?

Jadikecepoton budi berjulan adoloh $89,6 \frac{\mathrm{m}}{\text { ment }}$

Gambar n. Hasil Pekerjaan Subjek 2 dalam menuliskan kesimpulan

S2.26 : Jadi, panjang langkah/menit ialah 89,6 meter/menit

\section{Subjek 3 dalam menyelesaikan soal PISA}

Kemampuan berpikir reflektif Subjek 3 dalam menyelesakan soal 2.

a. Fase Reacting

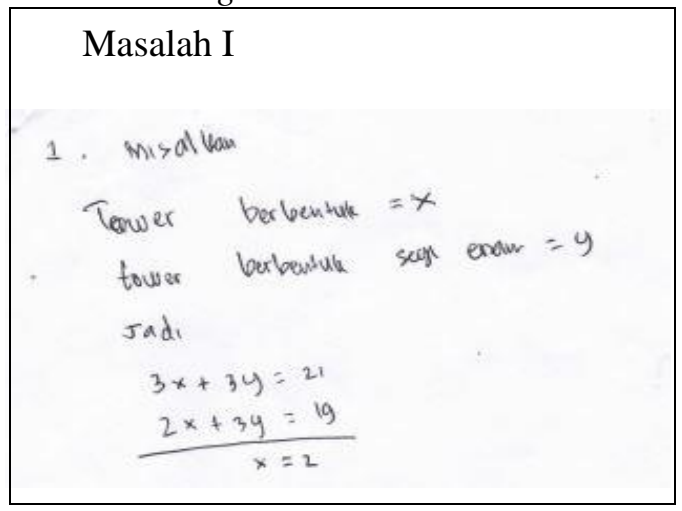

Gambar 7. Hasil Subjek 3 Fase Reacting

Berdasarkan Gambar 7, menunjukkan bahwa pada masalah I subjek 3 dapat menuliskan informasi yang diketahui sesuai dengan masalah yang diberikan, namun tidak menuliskan apa yang ditanyakan pada soal. Ketika wawancara dilakukan, subjek mampu mengemukakan apa yang ditanyakan pada soal.

Berdasarkan uraian di atas, maka dapat disimpulkan bahwa pada fase reacting, subjek 3 mampu dalam menuliskan infomasi yang diketahui dengan benar

Petikan wawancara Subjek 3 berkaitan dengan fase reacting sebagai berikut:

P 06 : Informasi apa saja yang kamu peroleh dari masalah I? 


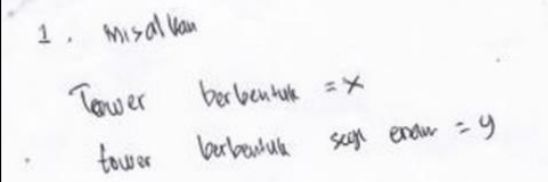

Gambar o. Hasil Pekerjaan Subjek 3 memisalkan segi enam dengan $x$ dan persegi panjang dengan $y$

S3.06 : Pertama, aku Misalkan bangun datar segi empat ialah $x$ dan segienam ialah $y$.

P 07 : Apa yang ditanyakan dari soal ?

mava bugan tower adalahe
$2 x+y$

Gambar p. Hasil Pekerjaan Subjek 3 menentukan yang ditanyakan pada soal

S3.07 : Yang ditanya, berapakah tinggi tower terpendek? (sambil menunjuk)

P 08 : Apa hubungan antara yang di diketahui dan ditanya?

S3.08 : Hubungannya ialah dari yang diketahui kita bisa buat persamaan berdasarkan informasi pada gambar, yaitu $3 x+3 y=$ 21 persamaan pertama dan $3 x+2 y=$ 19 ialah persamaan kedua. Dari kedua persamaan ini, nantinya kita bisa menentukan nilai $x$ dan $y$ agar bisa menentukan tinggi tower terpendek.

P 09 : Apakah yang diketahui dan yang ditanyakan sudah cukup untuk menjawab soal ini?

S3.09 : Cukup

\section{b. Fase Comparing}

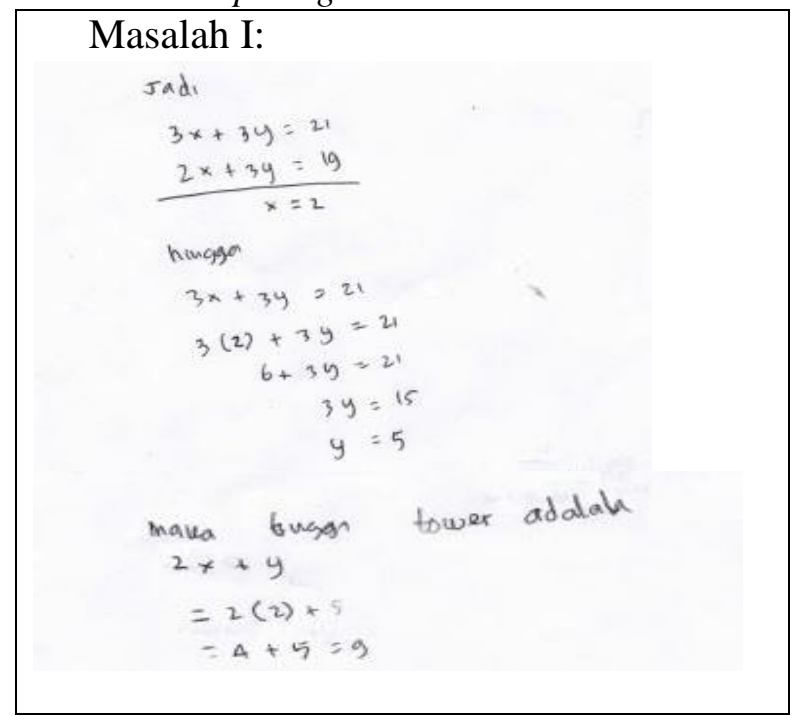

Gambar 8. Hasil Subjek 3 Fase Comparing

Petikan wawancara Subjek 3 berkaitan dengan fase comparing sebagai berikut:

P 10 : Pada soal no 1, Apakah pernah memecahkan soal seperti ini sebelumnya?
S3.10 : Pernah. Soal ini berkaitan dengan konsep SPLDV dan materi ini salah satu materi favorit.

P 11 : Coba jelaskan soal yang pernah dihadapi, kaitannya dengan masalah SPLDV?

S3.11: Misalkan $x+y=5$, persamaan pertama dan $x-y=1$ ialah persamaan kedua. Untuk menentukan nilai $x$ dan $y$ maka kita gunakan metode eliminasi dan subtitusi.

Pertama kita tuliskan persamaan pertama dan kedua

$x+y=5$

$x-y=1$

Selanjutnya kita eliminasi $x$ untuk menentukan nilai y. sehingga kita peroleh $2 y=6$ maka, $y=3$.

Selanjutnya kita gunakan metode subtitusi untuk menentukan nilai $x$.

Kita masukan persamaan pertama dan subtitusikan nilai $y$

$x+y=5$

$x+2=5$

$x=5-2$

$x=3$

Jadi, kita peroleh nilai $x$ dan $y$ ialah 3 dan 2

P 12 : Baik, kira-kira apa hubungan antara masalah yang pernah dihadapi dengan masalah yang di selesaikan sekarang?

S3.12 : Hubungannya ialah masalah yang pernah dihadapi dengan masalah yang sekarang sama-sama punya masalah yang sama yaitu menentukan nilai $x$ dan $y$. Dan masalah yang pernah aku hadapi menjadi pengalaman penting untukku sehingga bisa menyelesaikan masalah yang sekarang.

P 13 : Baik, cukup.

\section{c. Fase Contemplating}

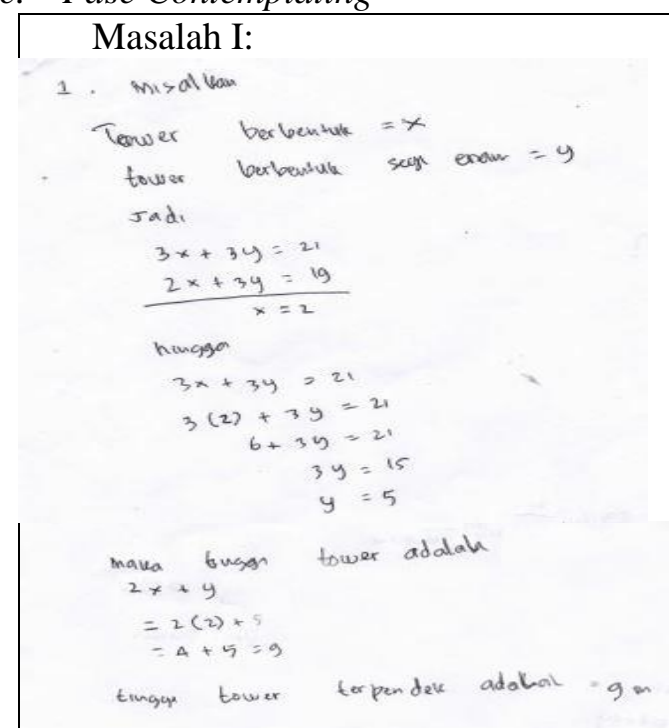

Gambar 9. Hasil Subjek 3 Fase Contemplating 
Berdasarkan Gambar 9, terlihat bahwa pada masalah I subjek 3 dapat menyelesaikan soal yang diberikan, menuliskan yang diketahui secara lengkap dan penarikan kesimpulan. Sehingga dapat disimpulkan bahwa pada fasecontemplating subjek 3 mampu dalam menjelaskan maksud permasalahan dan kesimpulan

Petikan wawancara Subjek 3 berkaitan dengan fase contemplating sebagai berikut:

P 14 : Dari soal no 1, kira-kira apa maksud dari soal?

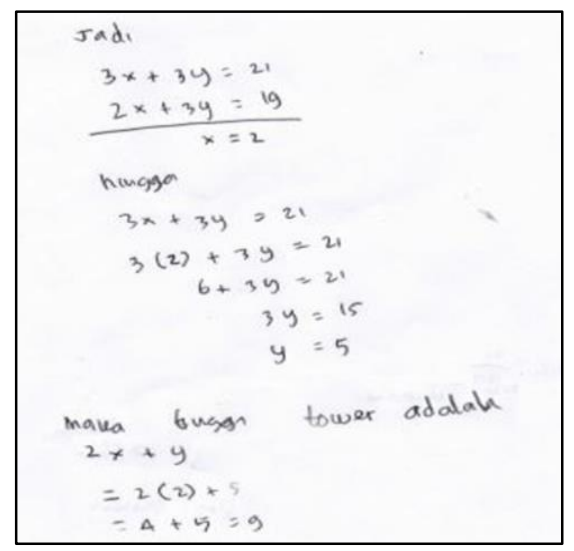

Gambar q. Hasil Pekerjaan Subjek 3 menggunakan metode eliminasi dan substitusi

S3.13 : Dari persamaan ini (Menunjuk hasil pekerjaan), kita menggunakan subtitusi dan eliminasi untuk mencari panjang bangun ini (menunjuk soal)

Pertama, kita misalkan bangun datar segi enam adalah $x$ dan persegi panjang adalah $y$. Selanjutnya berdasarkan informasi dari soal kita tulis persamaan yaitu $3 x+3 y=21 \mathrm{~cm}$ dan $3 x+2 y=$ $19 \mathrm{~cm}$. Setelah itu kita lakukan metode eliminasi pada $x$, dan kita peroleh nilai $y=2$. Selanjutnya kita tulikan persamaan $\quad 3 x+2 y=19$ dan subtitusikan nilai $y=2$, sehingga kita peroleh nilai $x=5$. Pada langkah terakhir, $x+2 y=5+2.2=9$

P 15 : Apakah dalam mengerjakan soal, terjadi kesalahan dan anda mengoreksinya ?

S3.13 : Tidak

P 16 : Bagaimana kesimpulan yang dapat diperoleh dari soal?

S3.15 : Jadi, tinggi tower terpendek ialah $9 \mathrm{~cm}$

Kemampuan berpikir analitik Subjek 3 dalam menyelesakan soal 2.

a. Fase Differentiating

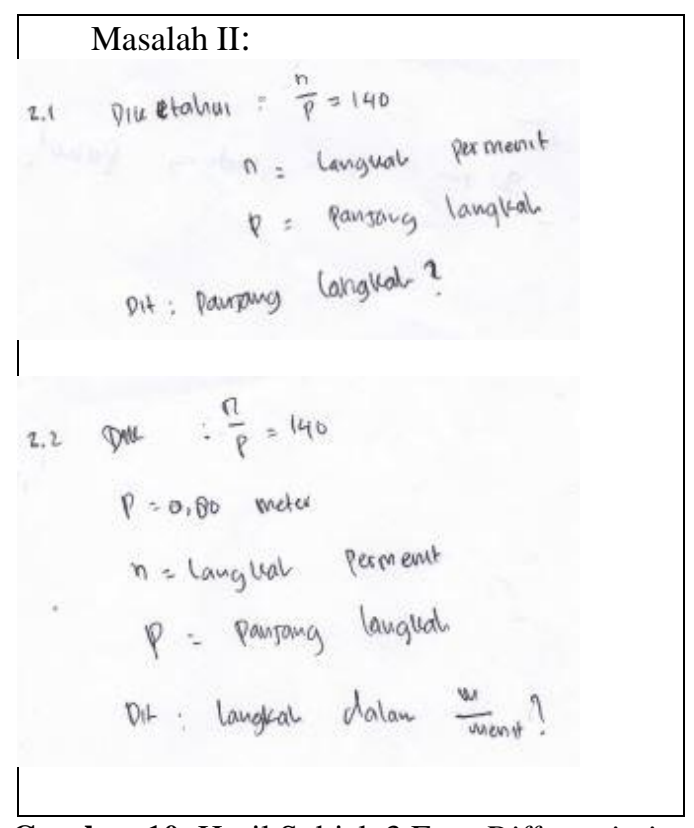

Gambar 10. Hasil Subjek 3 Fase Differentiating

Berdasarkan Gambar 10, terlihat bahwa pada masalah II, subjek 3 mampu menuliskan langkah-langkah penyelesaian masalah secara runtut. Pada jawaban di atas, terlihat bahwa subjek 3 memenuhi aspek memilih (differentiating) yaitu mampu mengelompokkan data-data yang berkaitan dengan permasalahan yang diberikan. pada masalah II, subjek 3 menuliskan data yang diketahui dan yang ditanyakan pada soal.

Petikan wawancara Subjek 3 berkaitan dengan fase differentiating sebagai berikut:

P 17 : Sekarang perhatikan lagi soal nomor 2. Informasi apa saja yang dapat di peroleh?

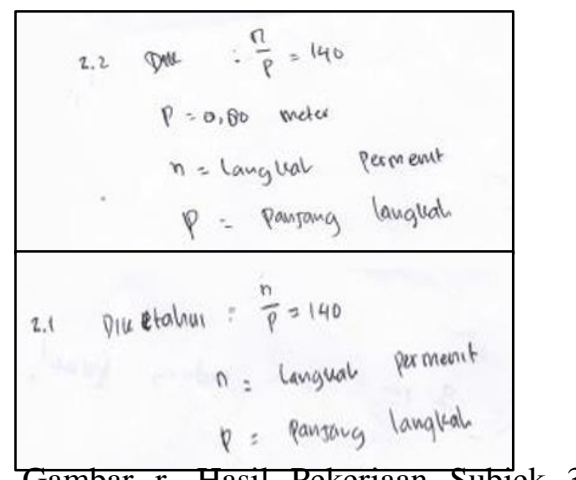

Gambar r. Hasil Pekerjaan Subjek 3 dalam menuliskan informasi yang dketahui dalam penyelesaian soal Diketahui $n / p=140$ dengan $\mathrm{n}=$ langkah permenit, dan $\mathrm{p}=$ panjang langkah.

P 18 : Terus informasi apa lagi?

S3.17

\begin{tabular}{|c|c|c|}
\hline parrpong & (ang) & at? \\
\hline Dit: langkal & dalan & $\frac{w}{\text { ments? }}$ \\
\hline
\end{tabular}


Gambar s. Hasil Pekerjaan Subjek 3 dalam menuliskan informasi yang ditanya dalam penyelesaian soal Pada soal no 2 ditanyakan pertama $\mathrm{p}$ atau panjang langkah dan $n$ langkah dalam meter/menit

P 19 : Jadi, bagian manakah yang menurutmu penting dalam soal?

S3.18 : Yang penting ialah kita bisa memahami maksud dari soal, yang diketahui dan ditanya. Jadi kita disuru untuk menentukan panjang langkah dan langkah dalam meter/menit.

P 20 : Menurut kamu informasi yang diperoleh apakah sudah cukup untuk menyelesaikan soal?

S3.19 : Cukup

\section{b. Fase Organizing}

b. Fase Organi

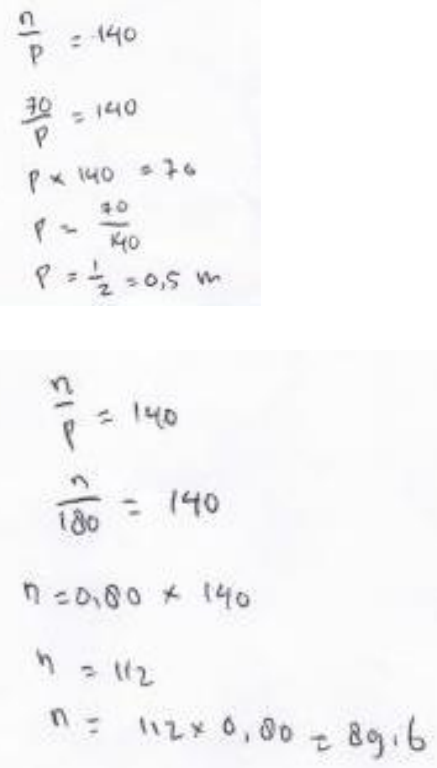

Gambar 11. Hasil Subjek 3 Fase Organizing

Berdasarkan Gambar 11. terlihat bahwa pada masalah II, subjek 3 mampu menuliskan langkah-langkah penyelesaian secara runtut. Pada jawaban di atas, terlihat bahwa subjek S3 memenuhi aspek organizing yaitu mampu membuat struktur dalam penyelesaian masalah yang sistematis.

Pada masalah II subjek S3 menggunakan konsep perbandingan senilai. Berdasarkan informasi dari soal, $\frac{n}{p}=140$ selanjutnya subjek S2 mensubtitusikan nilai $n=70$ sehingga, $\frac{70}{p}=$ 140. Maka $p=\frac{70}{140}=\frac{1}{2}=0,5$ sehingga diperoleh panjang langkah ialah $0,5 \mathrm{~m}$. selanjutnya untuk menentukan panjang langkah $\mathrm{m} /$ menit, subjek S3 mensubtitusikan nilai $p=0,80$. Sehingga diperoleh $\frac{n}{0,80}=140$. Maka, $n=0,80 \times 140=$ 112. $n=112 \times 0,80=89,6$.

Petikan wawancara Subjek 3 berkaitan dengan fase organizing sebagai berikut:

P 22 : Bagaimanakah strategi dan langkahlangkah dalam penyelesaian no 2.1 ?

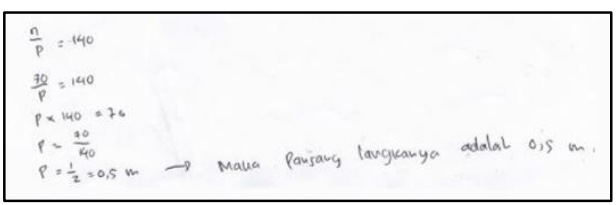

Gambar t. Hasil Pekerjaan Subjek 3 berkaitan dengan strategi dan langkahlangkah dalam penyelesaian soal

S3.21 : Iya, pertama kita tulis dulu persamaan berdasarkan informasi pada soal, $\frac{n}{p}=$ 140. Selanjutnya dari persamaan tersebut kita subtitusikan nilai $n$ berdasarkan informasi yang diketahui pada soal. Menjadi $\frac{70}{p}=140$ Selanjutnya kita terapkan manipulasi aljabar sehingga diperoleh nilai $p=0,5$ $\mathrm{m}$

P 23 : Pada soal no 2.2, Bagaimanakah strategi dan langkah-langkah dalam penyelesaian?

$\frac{n}{p}=140$
$\frac{n}{180}=140$
$n=0,80 \times 140$
$n=112$
$n=112 \times 0,00=89.6$
Kecepata bersalar addal $89.6 \frac{\mathrm{m}}{w e n 4}$

Gambar u. Hasil Pekerjaan Subjek 3 berkaitan dengan strategi dan langkahlangkah dalam penyelesaian soal

S3.22 : No 2.2 hampir sama dengan soal 2.1 karena nilai $p=0,80$ maka kita subtitusikan dalam persamaan $\frac{n}{p}=140$, Selanjutnya dari persamaan tersebut kita subtitusikan nilai $p$ berdasarkan informasi yang diketahui pada soal. Menjadi $\frac{n}{0,80}=140$ selanjutnya kita lakukan manipulasi aljabar sehingga diperoleh $n=89,6$

\section{c. Fase Attributing}

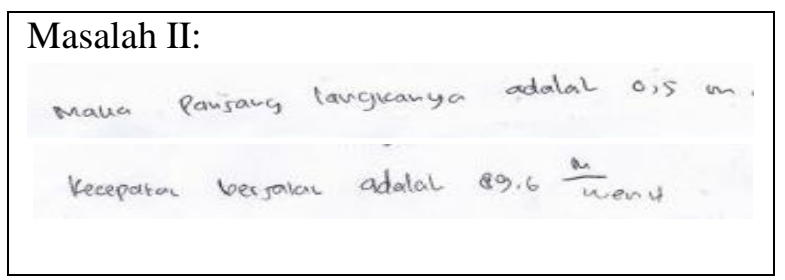

Gambar 12. Hasil Subjek 3 Fase Attributing 
Berdasarkan Gambar 12, terlihat bahwa pada masalah II, subjek 3 mampu menuliskan informasi dalam bentuk kesimpulan. Pada jawaban di atas, terlihat bahwa subjek S3 memenuhi aspek attributing yaitu mampu membuat kesmpulan berdasakan informasi yang diperoleh.

Petikan wawancara Subjek 3 berkaitan dengan fase attributing sebagai berikut:

P 21 : Pada soal no 2.1 apa kesimpulan yang bisa diperoleh?

Mana Pansany langkeanya adalal 0,5 m

Gambar v. Hasil Pekerjaan Subjek 3 dalam menuliskan kesimpulan

S3.20 : Jadi, panjang langkahnya ialah 0,5 m

P 24 : Pada soal no 2.2 apa kesimpulan yang bisa diperoleh?

Keeepatar versalar adalal $89,6 \frac{M}{\text { wend }}$

Gambar w. Hasil Pekerjaan Subjek 3 dalam menuliskan kesimpulan

S3.23 : Jadi, panjang langkah/menit ialah 89,6 meter/menit

\subsection{Pembahasan}

Berdasarkan hasil deskripsi dan analisis data yang telah dilakukan di atas, telah ditunjukkan kemampuan berpikir reflektif dan analitik peserta didik dalam menyelesaikan soal programme for international student assessment (PISA). Berikut ini adalah pembahasan mengenai kemampuan berpikir reflektif dan analitik peserta didik dalam menyelesaikan soal programme for international student assessment (PISA).

a. Analisis Kemampuan berpikir reflektif peserta didik dalam menyelesaikan soal programme for international student assessment (PISA)

Subjek 1 dengan kemampuan berpikir reflektif mampu memenuhi aspek reacting dan comparing namun kurang pada fase contemplating pada soal yang diberikan. Hal ini ditandai dengan Subjek mampu menyebutkan hal-hal yang diketahui dan ditanyakan, menyebutkan hubungan yang diketahui dan ditanyakan, menjelaskan dan menghubungkan jawaban pada permasalahan yang pernah didapatkan, menjelaskan maksud permasalahan, menjelaskan maksud permasalahan dan mengoreksi kesalahan pada penentu jawaban.

Hasil penelitian pada Subjek 1 menunjukkan bahwa Subjek 1 memenuhi indikator kemampuan berpikir reflektif. Menurut Fuady (2017: 110), Berpikir reflektif tidak tergantung pada pengetahuan peserta didik semata, tapi proses bagaimana memanfaatkan pengetahuan yang telah dimilikinya untuk memecahkan masalah yang dihadapi. Jika peserta didik mampu menemukan cara memecahkan masalah yang dihadapi sehingga dapat mencapai tujuannya maka peserta didik tersebut telah melakukan proses berpikir reflektif. Untuk itu anak perlu dilatih untuk bisa berpikir reflektif. Jika dilihat pada hasil pemecahan soal PISA yang diselesaikan oleh Subjek 1 terlihat jelas bahwa Subjek 1 menggunakan pengetahuan yang telah dimilikinya yaitu metode eliminasi, subtitusi, konsep aljabar, dan perbandingan senilai serta lainnya yang berhubungan dengan pemecahan soal PISA yang diberikan.

Hal tersebut sejalan dengan pendapat Skemp (Suharna, 2018: 25) berpikir reflektif terjadi apabila mental merespons dari luar, mengolah informasi dari luar, mengolah informasi yang diterima dengan memformulasikan pengetahuan lama. Informasi/pengetahuan yang digunakan untuk merespons, berasal dari dalam diri (internal), bisa menjelaskan apa yang telah dilakukan, menyadari kesalahan dan memperbaikinya (jika ada kesalahan), dan mengomunikasikan ide dengan simbol atau gambar.

b. Analisis Kemampuan berpikir analitik peserta didik dalam menyelesaikan soal programme for international student assessment (PISA)

Subjek 2 dengan kemampuan berpikir analitik mampu memenuhi aspek memilah, aspek mengorganisasi dan aspek mengatribusi pada soal yang diberikan. Hal ini ditandai dengan Subjek mampu mengelompokkan data-data dari masalah yang diberikan, menyusun struktur cara penyelesaian masalah, serta mampu mengungkapkan informasi dalam bentuk kesimpulan. Subjek 2 menuliskan dengan lengkap aspek-aspek yang memenuhi kemampuan berpikir analitik.

Hasil penelitian ini sejalan dengan penelitian yang dilakukan oleh Febidiana (2019: 110) tentang Analisis Kemampuan Berpikir Analitik dalam menyelesaikan masalah geometri dengan model Advance Organize, hasil penelitian yang diperoleh ialah Kemampuan berpikir analitik peserta didik dalam menyelesaikan masalah geometri dengan model advance organize memenuhi tiga aspek yaitu aspek memilah, aspek mengorganisasi serta aspek mengatribusi.

Menurut Suherman dan Sukjaya (1990: 49) kemampuan analitik adalah kemampuan untuk merinci atau menguraikan suatu masalah (soal) menjadi bagian-bagian yang lebih kecil 
(komponen) serta mampu untuk memahami hubungan diantara bagian-bagian tersebut. Hal ini diperkuat juga oleh Bloom yang menyatakan bahwa kemampuan berpikir analitik menekankan pada pemecahan materi kedalam bagian-bagian yang lebih khusus atau kecil dan mendeteksi hubungan-hubungan dan bagian-bagian dan bagian-bagian itu diorganisir.

Hasil penelitian yang diperoleh berbeda dengan hasil penelitian yang dilakukan oleh Viyanti (2019) tentang kemampuan berpikir analitik peserta didik dalam memecahkan masalah matematika studi komparatif siswa gaya kognitif visual verbalizer, hasil penelitian yang didapat adalah kemampuan berpikir analitik peserta didik visualizer pada tahap memahami masalah, merencanakan penyelesaian, melakukan rencana penyelesaian dan melihat kembali penyelesaian tergolong baik pada semua indikator, kecuali pada indikator menjelaskan keterkaitan antara strategi yang digunakan dengan masalah yang diselesaikan. Kemampuan berpikir analitik verbalizer dalam memecahkan masalah matematika pada tahap memahami masalah, merencanakan penyelesaian, melakukan rencana penyelesaian dan melihat kembali penyelesaian tergolong baik pada semua indikator, kecuali indikator menimpulkan masalah dan menarik kesimpulan dari hasil penyelesaian.

c. Analisis Kemampuan berpikir reflektif dan analitik peserta didik dalam menyelesaikan soal programme for international student assessment (PISA)

Subjek 3 dengan kemampuan berpikir reflektif mampu memenuhi aspek reacting, elaboration/comparing dan contemplating pada masalah I. Hal ini ditandai dengan Subjek 3 mampu menyebutkan hal-hal yang diketahui dan ditanyakan, menyebutkan hubungan yang diketahui dan ditanyakan, menjelaskan dan menghubungkan jawaban pada permasalahan yang pernah didaptkan, menjelaskan maksud permasalahan, menjelaskan maksud permasalahan.

Pada masalah II, Subjek 3 memenuhi indikator kemampuan berpikir analitik yaitu aspek memilah, aspek mengorganisasi dan aspek mengatribusi, hal ini ditandai dengan Subjek 3 mampu mengelompokkan data-data dari masalah yang diberikan, menyusun struktur cara penyelesaian masalah, serta mampu mengungkapkan informasi dalam bentuk kesimpulan.

\section{Kesimpulan}

Kemampuan berpikir reflektif subjek 1 memenuhi indikator kemampuan berpikir reflektif. Pada fase reacting subjek 1 mampu dalam menyebutkan hal-hal yang diketahui dalam soal, menyebutkan yang ditanyakan dalam soal, menyebutkan hubungan antara yang diketahui dengan yang ditanya dan mampu menjelaskan yang diketahui sudah cukup atau belum untuk menjawab yang ditanyakan. Pada fase comparing subjek 1 mampu dalam menjelaskan jawaban pada permasalahan yang pernah didapatkan dan menghubungkan masalah yang ditanyakan dengan masalah yang pernah dihadapi. Pada fase contemplating, subjek 1 mampu dalam menjelaskan maksud permasalahan, mengoreksi kesalahan pada penentu jawaban, kurang dalam memperbaiki dan menjelaskan jika terjadi kesalahan dari jawaban juga tidak membuat kesimpulan di akhir jawaban.

Kemampuan berpikir analitik subjek 2 memenuhi indikator kemampuan berpikir analitik. Pada fase differentiating, subjek 2 mampu dalam memilah-milah bagian-bagian yang relevan dan tidak relevan, pada fase organizing mampu dalam membuat struktur dalam penyelesaian masalah yang sistematis dan pada fase attributing mampu dalam mengungkapkan informasi dalam bentuk kesimpulan.

Kemampuan berpikir reflektif dan analitik subjek 3 memenuhi indikator kemampuan berpikir reflektif. Pada fase reacting subjek 3 mampu dalam menyebutkan hal-hal yang diketahui dalam soal, menyebutkan yang ditanyakan dalam soal, menyebutkan hubungan antara yang diketahui dengan yang ditanya dan mampu menjelaskan yang diketahui sudah cukup atau belum untuk menjawab yang ditanyakan. Pada fase comparing subjek 3 mampu dalam menjelaskan jawaban pada permasalahan yang pernah didapatkan dan menghubungkan masalah yang ditanyakan dengan masalah yang pernah dihadapi. Pada fase contemplating, subjek 3 baik dalam menjelaskan maksud permasalahan, mengoreksi kesalahan pada penentu jawaban, memperbaiki dan menjelaskan jika terjadi kesalahan dari jawaban dan membuat kesimpulan dengan benar.

\section{Daftar Pustaka}

Amer, Aiman. 2005. Analythical Thinking. Cairo: Cairo University (CAPSCU)

Ananda. 2019. Analisis Kemampuan Berpikir Reflektif Matematis Dalam Menyelesaikan Soal Operasi Pecahan Campuran Pada Kelas VII Sekolah Menengah Pertama Negeri 14 Satu Atap 
Tanjungpinang (FKIP: Universitas Maritim Raja Ali Haji Tanjung Pinang)

Febriana Della Putri, 2019. Analisis Kemampuan Berpikir Analitik Dalam Menyelesaikan Masalah Geometri Dengan Model Advance Organize (FKIP: Uin Sunan Ampel, Surabaya)

Fuady Anies. 2017. Berfikir Reflektif Dalam Pembelajaran Matematika. Volume 1 Nomor 2, hal. 110.

Gurol, A. 2011. Determining the Reflective Thinking Skill of Pre-service Teacher in Learning and Teaching Process. Energi Education Science and Technologi Part B: Social and Educational Studies 2011 Volume (issue) 3(3): 387-402

Kurniati, D., Harimukti, R., \& Jamil, N. A. (2016). Kemampuan berpikir tingkat tinggi siswa SMP di Kabupaten Jember dalam menyelesaikan soal berstandar PISA. Jurnal Penelitian dan Evaluasi Pendidikan, 20(2), 142-155.

Muin, A. (2011). "The Situations that Can Bering Reflective Thinking Process in Mathematics Learning". International Seminar and the Fourth Natinal Conference on Mathematics Education Department of Mathematics Education. (pp. 231238). Yogyakarta State University. Yogyakarta.

Nindisari Hepsi., Kusumah Yaya, Sumarmo Utari., Sabandar Jozua, 2014. Pendekatan Metakognitif Untuk Meningkatkan Kemampuan Berpikir Reflektif Matematis Siswa SMA. Jurnal Ilmu Pendidikan dan Pengajaran. Vol. 1 No. 1, Maret 2014. hal. 82.

OECD. (2014). PISA 2012 Results: What Students Know and Can Do - Student Performance in Mathematics, Reading and Science (Volume I, Revised edition, February 2013). PISA, OECD Publishing.
Parta, I. N. (2016). Karakteristik Berpikir analitik Mahasiswa dalam Menyelesaikan "Masalah Sederhana". Malang: Universitas Negeri Malang.

Rodgers, C., 2002. Definiting Reflection: Another Look at John Dewey and Reflective Thinking. Teachers College Record Volume 104, Number 4, June 2002, pp. 842-866. Columbia University

Sabandar, J. (2010). Berpikir Reflektif dalam Pembelajaran Matematika.(Pascasarjana: Pendidikan Matematika Universitas Pendidikan Indonesia)

Setiawan, H. (2014). Soal matematika dalam PISA kaitannya dengan literasi matematika dan keterampilan berpikir tingkat tinggi. In Prosiding Seminar Nasional Matematika, Universitas Jember.

Sternberg, Robert J., Karin Sternberg. 2012. Cognitive Psychology. Sixth Edition. Wadsworth. USA

Suharna, Hery. 2012. Teori berpikir reflektif dalam menyelesaikan masalah matematika. Yogyakarta: CV Budi Utama.

Suherman, E. dan Sukjaya, Y. 1990. Petunjuk Praktis Untuk Melaksanakan Evaluasi Pendidikan Matematika. Bandung: Wijayakusumah.

Sulastri dkk, Pengaruh Strategi Pembelajaran Critical Incident terhadap Keterampilan Analisis Siswa (FKIP: Universitas Prof Dr. Hamka, Jakarta)

Viyanti Pratiwi, 2019. Kemampuan Berpikir Analitik Peserta Didik Dalam Memecahkan Masalah Matematika di Mi Ma'aruf Pagerwojo Buduran Sidoarjo Studi Komparatif Siswa Gaya Kognitif Visual Verbalizer, (Pascasarjana: UIN Sunan Ampel, Surabaya). 